\title{
Perceived emotional intelligence of teachers and their pupils' academic performance
}

\author{
Mansanadez, Evangeline A. \\ Jose Rizal Memorial State University - Tampilisan Campus, Philippines (evangelinemansanadez@gmail.com)
}

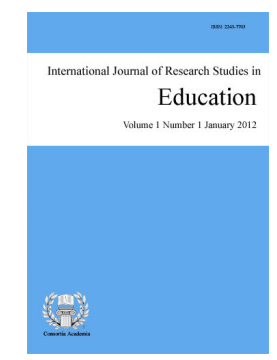

ISSN: 2243-7703 Online ISSN: 2243-7711

OPEN ACCESS

\section{Abstract}

This study aimed to determine the emotional intelligence of teachers and the academic performance of pupils in Tampilisan District in which findings will be the basis for a proposed program to improve the teaching performance of teachers. It made use of the descriptive-quantitative survey method of research, employing a modified questionnaire-checklist, involving the 428 respondents comprising the teachers, school heads, and pupils. Data were analyzed using frequency count, ranking, weighted mean, Chi-Square test and Analysis of Variance (ANOVA). Findings revealed that "self-awareness" is the prevalent emotional intelligence of teachers. The level of teacher's emotional intelligence is "very emotionally intelligent". Majority of the pupils obtained a "good" academic performance. Chi-Square Test indicates that teacher's emotional intelligence has no significant influence to the pupil's academic performance. In terms of the respondents' perceptions towards the emotional intelligence of teachers, results revealed a significant difference on self-awareness and relationship management but an insignificant difference existed on self-management and social awareness. When this difference was further treated using post-hoc analysis, the significant difference existed between the pupils' and the teacher's perceptions. These findings led to the conclusion that teachers are very emotionally intelligent and the pupils performed considerably well in their academic subjects.

Keywords: emotional intelligence; academic performance; self-awareness; self-management; social awareness; relationship management 


\section{Perceived emotional intelligence of teachers and their pupils' academic performance}

\section{Introduction}

Teaching, as a common knowledge, is a noble profession. There are no other professions without the teaching profession. It is a vocation that requires perseverance since it demands special commitment. In teaching, teachers are expected to possess unique qualities such as emotional intelligence, convincing power and a heart that motivates students to learn from them because these can possibly be one of the many factors that contribute in making their teaching performance better and for the students to achieve learning.

Accordingly, teachers in the basic education faced various tasks every day from the very start of their services until retirement. Their role varies from that of their pupils, their classrooms, respective schools, stakeholders, parents and the community people. All of these contribute much to having a very stressful challenge on their part. As observed, a teacher in the elementary is tasked to culture the mind, values and skills of the pupils, especially nowadays that the K-12 program has been fully implemented. However, resources are not enough and teachers are left behind to always find ways and means to cater everything needed to realize what has been implemented in order to educate the young learners. In addition to this, the 21 st century learners are quite different from the learners in the older generations because of the acquisition and influence of technology. These are some of the many factors that require teachers' emotional intelligence to carry on with their teaching profession.

Emotional intelligence is the ability to understand, use, and manage one's own emotions in positive ways to relieve stress, communicate effectively, empathize with others, overcome challenges and defuse conflict (HelpGuide, 2020) while Raz and Zysberg (2014) both cited by O'Shea (2019) noted that teaching is a profession with high levels of emotional labor.

Rust (2014) claimed that emotional intelligence provides meaningful answers for a successful working relationship between teachers and learners in the classroom. Findings of the study conducted by Alam and Ahmad (2018) revealed that the relationship between emotional intelligence and student achievement is mediated by school culture; while Valente et al. (2019) also disclosed that teachers who have more capacity to deal with emotion demonstrate a greater management of discipline in the classroom. These findings support the claims of Curci et al. (2014) which emphasized that teachers' emotional intelligence has a positive role in promoting students' achievement by enhancing the effects of students' self-perceptions of ability and self-esteem. That is why, in order to make it possible, they recommend an implementation of intervention programs on the emotional, motivational, and metacognitive correlates of studying and learning behavior.

On the other hand, result of the study conducted by Dolev and Leshem (2016) indicate that emotional intelligence can be develop in teachers and recommended that the EI training programs may be effective in bringing about positive EI shifts and related behaviors which they believed to positively impact upon teachers' practice, their sense of meaningfulness and their relations with students. Likewise, Vesely et al. (2013) also recommended that EI training may increase teacher's efficacy in the classroom and decrease their stress and job dissatisfaction.

\subsection{Theoretical framework of the study}

This study is anchored on the Emotional Intelligence Theory proposed by Daniel Goleman (1995) and developed by Mayer and Salovey (1997). Goleman says that at best, Intelligence Quotient (IQ) contributes about $20 \%$ to the factors that determine life success which leaves $80 \%$ to other forces. He believes that these forces may be influenced by emotions. If emotional intelligence contributes $80 \%$ to a person's success, how can this be applied in the teaching profession? One of the challenges in determining the value of emotional intelligence to 
Perceived emotional intelligence of teachers and their pupils' academic performance

life success is to specifically determine its influence on the success of a person in the teaching profession. He defined emotional intelligence as the capacity for recognizing one's own feelings and those of others, for motivating oneself, and for managing emotions well in oneself and in one's relationships.

According to the HelpGuide Org. International (2020), Goleman's Emotional Intelligence has four domains. The first domain is self-awareness which means recognition of emotions and how they affect thoughts and behavior. It includes knowing the strength and weaknesses and having self-confidence. The second domain is self-management where one is able to control impulsive feelings and behaviors, manage emotions in healthy ways, take initiative, follow through on commitments and adapt to changing circumstances. The third domain is social awareness where one has empathy, understands the emotions, needs and concerns of other people, picks up on emotional cues, feels comfortable socially, and recognizes the power dynamics in a group or organization. The fourth domain is relationship management where one knows how to develop and maintain good relationships, communicate clearly, inspire and influence others, work well in a team, and manage conflict.

The aforementioned theory of Daniel Goleman provided the basis for the kinds of emotional competencies that influence success on the teaching performance. Effective and good teachers have a positive relationship with their students. Teaching effectively requires command of what is being taught but that knowledge alone does not produce student learning. There is more to it. It requires emotional intelligence.

\subsection{Objectives}

This study aimed to determine the following objectives:

$>$ The prevalent emotional intelligence of teachers in Tampilisan District as to self-awareness, self-management, social awareness, and relationship management.

$>$ The level of emotional intelligence of teachers as perceived by the teachers themselves, principals/school heads, and pupils in terms of self-awareness, self-management, social awareness, and relationship management.

$>\quad$ The academic performance of pupils in Tampilisan District when grouped according to school.

$>\quad$ The influence of emotional intelligence of teachers on the academic performance of pupils in Tampilisan District.

$>\quad$ Difference on the level of emotional intelligence of teachers as perceived by the three groups of respondents.

$>$ Measures proposed to improve the teaching performance of teachers in Tampilisan District.

\section{Research method}

This study made use of the descriptive-quantitative survey method of research employing a modified questionnaire-checklist to gather the necessary data on the emotional intelligence of teachers and the academic performance of pupils. It was conducted at the nine (9) randomly selected elementary schools of Tampilisan District, municipality of Tampilisan, province of Zamboanga del Norte, Philippines. The respondents of the study were the nine (9) school heads/principals, 40 teachers and 379 students of Grades IV-VI with a total of 428, in the selected elementary schools of the district under study. The school heads/principals and teachers were considered by total enumeration while $30 \%$ only of the total population of the pupil-respondents of Grades IV-VI in each school under study were considered as respondents of the study.

In gathering the needed data to determine the emotional intelligence of teachers and the academic performance of pupils in the district under study, the researcher made use of a modified questionnaire-checklist adapted from the EI questionnaire of Daniel Goleman (1995). Three sets of questionnaires were prepared by the 
Mansanadez, E. A.

researcher intended for the three groups of respondents. The instrument used by the pupil-respondents was translated into a vernacular language to be understood by them. The instrument used consists of 10 item statements in every emotional intelligence indicator as to self-awareness, self-management, social awareness and relationship management using the rating scale below:

\begin{tabular}{|c|c|c|c|}
\hline Rating scale: & \multicolumn{2}{|c|}{ Description: } & Qualification: \\
\hline 4 & SA/VEI & Strongly Agree & $\begin{array}{l}\text { The teacher is Very Emotionally Intelligent because } \\
\text { the statement always applies to him/her }\end{array}$ \\
\hline 3 & $\mathrm{~A} / \mathrm{EI}$ & Agree & $\begin{array}{l}\text { The teacher is Emotionally Intelligent because the } \\
\text { statement often applies to him/her }\end{array}$ \\
\hline 2 & D/LeEI & Disagree & $\begin{array}{l}\text { The teacher is Less Emotionally Intelligent because } \\
\text { the statement seldom applies to him/her }\end{array}$ \\
\hline 1 & SD/LeaEI & Strongly Disagree & $\begin{array}{l}\text { The teacher is Least Emotionally Intelligent because } \\
\text { the statement rarely applies to him/her }\end{array}$ \\
\hline
\end{tabular}

In determining the academic performance of pupils, the following continuum which was based on the DepEd K to 12 Grading System was used:

$\begin{array}{lll}95-100 & - & \text { Excellent } \\ 90-94 & - & \text { Very Good } \\ 85-89 & - & \text { Good } \\ 80-84 & - & \text { Fair } \\ 79-\text { below - } & \text { Needs Improvement }\end{array}$

Data were analyzed using frequency count, ranking, weighted mean, Chi-square and Analysis of Variance (ANOVA).

\section{Findings and discussion}

\subsection{On the prevalent intelligence of teachers}

Table 1 reflects the prevalent emotional intelligence of teachers in Tampilisan District. Data show that self-awareness is the prevalent emotional intelligence (EI) of teachers which registered a weighted mean of 3.53. The result implies that the respondents are more aware of themselves and their emotions. This result is in consonance with the findings of the study conducted by Tolloczko (2015) which found a correlation between the level of emotional intelligence and ability to cope in educational situations. She emphasized that understanding one's own and other people's emotions favours achieving high educational competences. This finding implies further that teachers who are more aware of their and other's feelings and emotions are more effective and efficient in their teaching profession, thus making their pupils obtain more learning.

\section{Table 1}

Prevalent emotional intelligence of teachers in Tampilisan district

\begin{tabular}{ccc}
\hline Emotional Intelligence & Mean & Rank \\
\hline Self-awareness & 3.53 & $1^{\text {st }}$ \\
Self-management & 3.47 & $4^{\text {th }}$ \\
Social awareness & 3.48 & $3^{\text {rd }}$ \\
Relationship management & 3.49 & $2^{\text {nd }}$ \\
\hline
\end{tabular}

\subsection{On the level of emotional intelligence of teachers}

Teacher's self-awareness - Table 2.1 presents the level of emotional intelligence of teachers as perceived by the three groups of respondents in terms of self-awareness. As reflected on the table, almost all item statements were rated "very emotionally intelligent" by the three groups of respondents in terms of self-awareness of the

78 Consortia Academia Publishing (A partner of Network of Professional Researchers and Educators) 
teachers which registered a weighted means of 3.64, 3.28, 3.43 and 3.45 respectively. This implies that the teachers are aware of their own emotions that they are able to recognize, understand and managed their emotional states and regulate their behavior. In other words, they can control their ill emotions by changing their negative way of thinking when facing a stressful situation into a positive one that helps them stay calm and feel better when upset.

The result is related to the idea of Santos (2008) which states that emotional maturity comes in a person when one accepts, recognizes, assesses and learns how to control emotions; willing to listen and be more considerate to others feelings and emotionally at peace and calm in dealing with the courses of life. The result of the study conducted by Asrar-ul-Haq et al. (2017) revealed that emotional self-awareness, self-confidence, achievement, developing others and conflict management have a positive and significant relationship with the teacher's job performance. On the other hand, Akmal et al. (2013) also revealed that their respondents have high level of emotional intelligence where the two domains of EI investigated such as Self-Emotion Appraisal and Understanding of Emotion are found to be significantly and positively associated with the pre-service teacher's academic achievement.

\section{Table 2.1}

EI of teachers as perceived by themselves, principals'/school heads and pupils in terms of self-awareness

\begin{tabular}{lcccccccc}
\hline \multicolumn{1}{c}{ Self-awareness } & \multicolumn{2}{c}{ Students } & \multicolumn{2}{c}{ Teachers } & \multicolumn{2}{c}{ Principal } & \multicolumn{2}{c}{ Grand mean } \\
& M & D & M & D & M & D & M & D \\
\hline $\begin{array}{l}\text { The teacher always knows which emotions } \\
\text { he/she is feeling and why. }\end{array}$ & 3.63 & VEI & 3.33 & VEI & 3.49 & VEI & 3.49 & VEI \\
$\begin{array}{l}\text { The teacher admits his/her own mistakes and } \\
\text { apologize. }\end{array}$ & 3.80 & VEI & 3.11 & EI & 3.09 & EI & 3.33 & VEI \\
$\begin{array}{l}\text { The teacher recognizes how his/her feelings } \\
\text { affect his/her performance. }\end{array}$ & 3.52 & VEI & 3.22 & EI & 3.45 & VEI & 3.40 & VEI \\
$\begin{array}{l}\text { The teacher has a guiding awareness of his/her } \\
\text { values and goals. }\end{array}$ & 3.69 & VEI & 3.44 & VEI & 3.27 & VEI & 3.47 & VEI \\
$\begin{array}{l}\text { The teacher realizes immediately when he/she } \\
\text { lose his/her temper. }\end{array}$ & 3.53 & VEI & 3.33 & VEI & 3.12 & EI & 3.33 & VEI \\
$\begin{array}{l}\text { The teacher manages his/her impulsive feelings } \\
\text { and distressing emotions well. }\end{array}$ & 3.59 & VEI & 3.33 & VEI & 3.31 & VEI & 3.41 & VEI \\
$\begin{array}{l}\text { The teacher realizes that as a person, he/she has } \\
\text { strengths and weaknesses. }\end{array}$ & 3.67 & VEI & 3.33 & VEI & 3.71 & VEI & 3.57 & VEI \\
$\begin{array}{l}\text { The teacher is reflective and tries to learn from } \\
\text { experience. }\end{array}$ & 3.76 & VEI & 3.33 & VEI & 3.75 & VEI & 3.61 & VEI \\
$\begin{array}{l}\text { The teacher is decisive and able to make sound } \\
\text { decisions despite uncertainties and pressure. }\end{array}$ & 3.52 & VEI & 3.22 & EI & 3.82 & VEI & 3.52 & VEI \\
$\begin{array}{l}\text { The teacher is able to show a sense of humor } \\
\text { and perspective about him/herself. }\end{array}$ & 3.67 & VEI & 3.11 & EI & 3.25 & EI & 3.34 & VEI \\
\hline
\end{tabular}

Teacher's self-management - Table 2.2 displays the level of emotional intelligence of teachers as perceived by the three groups of respondents in terms of self-management. The table shows that all item statements on self-management were rated "very emotionally intelligent" by the three groups of respondents with the grand mean value of 3.59, 3.41 and 3.43 respectively. This means that the teachers are perceived to be self-competent and have enough self-control. This means further that they have the ability to manage their own self and emotions that makes them flexible to engage in every challenging situations or stressful events in the classroom.

This finding is in relation to the theory of Santos (2016) who noted that when a person is emotionally imbalance and disturb and will not be able to accept and control one's emotions, a person may end deciding and doing a wrong thing, however, a person is emotionally stable if he/she can keep his/her temper under control and when he/she accepts and recognizes his/her feelings and assesses them in order to act uprightly. Santos emphasized that emotional stability comes when one is willing to listen, accept, understand others emotions, 
calm, and can work under pressure. Relatively, Adinalgnat et al. (2012) concluded that a good emotional intelligence of the teachers is correlated with a positive attitude towards work and with satisfaction with life and with work itself.

\section{Table 2.2}

EI of teachers as perceived by themselves, principals'/school heads and pupils in terms of self-management

\begin{tabular}{|c|c|c|c|c|c|c|c|c|}
\hline \multirow{2}{*}{ Self-management } & \multicolumn{2}{|c|}{ Students } & \multicolumn{2}{|c|}{ Teachers } & \multicolumn{2}{|c|}{ Principal } & \multicolumn{2}{|c|}{ Grand mean } \\
\hline & M & D & M & D & M & D & $\mathrm{M}$ & D \\
\hline $\begin{array}{l}\text { The teacher is good at managing his/her moods } \\
\text { and tries not to bring negative emotions to } \\
\text { work. }\end{array}$ & 3.61 & VEI & 3.44 & VEI & 3.45 & VEI & 3.50 & VEI \\
\hline $\begin{array}{l}\text { The teacher admits his/her mistakes and } \\
\text { apologize. }\end{array}$ & 3.37 & VEI & 3.33 & VEI & 3.38 & VEI & 3.36 & VEI \\
\hline $\begin{array}{l}\text { The teacher never interrupts other people's } \\
\text { conversations. }\end{array}$ & 3.39 & VEI & 3.33 & VEI & 3.25 & EI & 3.32 & VEI \\
\hline $\begin{array}{l}\text { The teacher waits until he/she has all the } \\
\text { pertinent information before expressing his/her } \\
\text { opinion. }\end{array}$ & 3.65 & VEI & 3.33 & VEI & 3.47 & VEI & 3.48 & VEI \\
\hline The teacher takes time for quiet reflection. & 3.62 & VEI & 3.44 & VEI & 3.46 & VEI & 3.51 & VEI \\
\hline $\begin{array}{l}\text { The teacher holds himself/herself accountable } \\
\text { for meeting his/her objectives. }\end{array}$ & 3.67 & VEI & 3.44 & VEI & 3.44 & VEI & 3.52 & VEI \\
\hline $\begin{array}{l}\text { The teacher is organized and careful in his/her } \\
\text { work. }\end{array}$ & 3.76 & VEI & 3.56 & VEI & 3.71 & VEI & 3.68 & VEI \\
\hline $\begin{array}{l}\text { The teacher seeks out fresh ideas from a wide } \\
\text { variety of sources. }\end{array}$ & 3.58 & VEI & 3.22 & EI & 3.55 & VEI & 3.45 & VEI \\
\hline $\begin{array}{l}\text { The teacher is flexible in how he/she sees } \\
\text { events. }\end{array}$ & 3.50 & VEI & 3.44 & VEI & 3.28 & VEI & 3.41 & VEI \\
\hline $\begin{array}{l}\text { The teacher has full authority on the subject } \\
\text { he/she is teaching. }\end{array}$ & 3.72 & VEI & 3.56 & VEI & 3.28 & VEI & 3.52 & VEI \\
\hline Grand mean & 3.59 & VEI & 3.41 & VEI & 3.43 & VEI & 3.47 & VEI \\
\hline
\end{tabular}

Teacher's social awareness - Table 2.3 reflects the level of emotional intelligence of teachers as perceived by themselves, principals'/school heads and students in terms of social awareness. As reflected on the table, almost all item statement were rated "very emotionally intelligent" by the three groups of respondents except item statement no. 2 "The teacher can show empathy and match his/her feelings with those of another person in an interaction", no. 3 "The teacher is always able to see things from the other person's viewpoint", and no. 4 "The teacher is always empathizing with someone else's problem" which were rated by the teachers themselves to be "emotionally intelligent" so with the pupils and principals. This means that these statements are often or frequently applicable to the teachers.

However, with a grand mean of $3.55,3.37,3.47$ and 3.46 respectively, the emotional intelligence of teachers in terms of social awareness is "very emotionally intelligent" which means, almost all item statements are always or at all times applicable to them. It implies that the three groups of respondents perceived the teachers to be emotionally matured, fit, can manage and control their own feelings and emotions when dealing with odd situations involving the people around them, specifically, their pupils, colleagues and the community people. This can be related to the argument presented by Lopez et al. (2019) which suggests that emotional intelligence has a specific buffering effect affecting intrapersonal and interpersonal processes. Additionally, Roja et al. (2013) also believed that an emotionally mature person is one who is able to keep a lid on feelings. He/she can suffer in silence. When he/she does express emotion, he/she does so with moderation, decently and in good order. Similarly, Baracsi (2016) found that the weakest part of teachers' emotional intelligence is the sense of their emotions and controlling them; however, they are eager to take care of other people and their strong wish for parity fosters social relationships. 
Table 2.3

EI of teachers as perceived by themselves, principals'/ school heads and pupils in terms of social awareness

\begin{tabular}{|c|c|c|c|c|c|c|c|c|}
\hline \multirow{2}{*}{ Self-awareness } & \multicolumn{2}{|c|}{ Students } & \multicolumn{2}{|c|}{ Teachers } & \multicolumn{2}{|c|}{ Principal } & \multicolumn{2}{|c|}{ Grand mean } \\
\hline & M & D & M & $\mathrm{D}$ & M & $\mathrm{D}$ & M & D \\
\hline $\begin{array}{l}\text { The teacher helps out based on understanding } \\
\text { other people's needs and feelings. }\end{array}$ & 3.54 & VEI & 3.44 & VEI & 3.75 & VEI & 3.58 & VEI \\
\hline $\begin{array}{l}\text { The teacher can show empathy and match } \\
\text { his/her feelings with those of another person in } \\
\text { an interaction. }\end{array}$ & 3.46 & VEI & 3.22 & EI & 3.53 & VEI & 3.40 & VEI \\
\hline $\begin{array}{l}\text { The teacher is always able to see things from } \\
\text { the other person's viewpoint. }\end{array}$ & 3.46 & VEI & 3.22 & EI & 3.23 & EI & 3.30 & VEI \\
\hline $\begin{array}{l}\text { The teacher is always empathizing with } \\
\text { someone else's problem. }\end{array}$ & 3.18 & EI & 3.11 & EI & 3.17 & EI & 3.15 & EI \\
\hline $\begin{array}{l}\text { While teaching, the teacher sees examples from } \\
\text { daily life situations. }\end{array}$ & 3.61 & VEI & 3.56 & VEI & 3.27 & VEI & 3.48 & VEI \\
\hline $\begin{array}{l}\text { The teacher keeps friendly and brotherly } \\
\text { relationship with his/her teacher colleagues. }\end{array}$ & 3.76 & VEI & 3.44 & VEI & 3.75 & VEI & 3.65 & VEI \\
\hline $\begin{array}{l}\text { The teacher respects the head of institution as } \\
\text { his/her senior most members. }\end{array}$ & 3.66 & VEI & 3.44 & VEI & 3.58 & VEI & 3.56 & VEI \\
\hline $\begin{array}{l}\text { The teacher always appreciates pupils' opinions } \\
\text { and demands. }\end{array}$ & 3.65 & VEI & 3.44 & VEI & 3.49 & VEI & 3.53 & VEI \\
\hline $\begin{array}{l}\text { The teacher uses more rewards and lesser } \\
\text { punishment in the classroom for achievement } \\
\text { of desired aims. }\end{array}$ & 3.54 & VEI & 3.44 & VEI & 3.46 & VEI & 3.48 & VEI \\
\hline $\begin{array}{l}\text { The teacher advises the pupils to solve their } \\
\text { problems according to their needs. }\end{array}$ & 3.60 & VEI & 3.33 & VEI & 3.46 & VEI & 3.46 & VEI \\
\hline Grand mean & 3.55 & VEI & 3.37 & VEI & 3.47 & VEI & 3.46 & VEI \\
\hline
\end{tabular}

Teacher's relationship management - Table 2.4 displays the level of emotional intelligence of teachers as perceived by themselves, principals'/school heads and students in terms of relationship management. Data on the table shows that almost all item statements were rated "very emotionally intelligent" by the respondents except item statement no. 2 "The teacher is approachable to the people who need him/her"; no. 4 "People generally like the teacher even if they don't always agree with him/her"; and no. 5 "The teacher mentors, give timely coaching, and offer assignment that challenge and grow a person's skill" which were rated "emotionally intelligent" by the teacher-respondents. This means that these statements are often or frequently applicable to them. This finding supports the result of the study conducted by Dolev and Leshem (2016) which disclosed that EI can be developed in teachers especially when they will engage themselves in EI training programs that might be effective in bringing about positive EI shifts and related behaviors within them which may positively impact upon their practice, their sense of meaningfulness and their relations with students. Similarly, Maillefer et al. (2018) recommended the emotional intelligence program as a direct and systematic component of professional development for teachers prior to and throughout their teaching career.

However, with a grand mean of 3.56, 3.36, 3.49 and 3.47, the emotional intelligence of teachers as perceived by the three groups of respondents is "very emotionally intelligent". This means that the teachers were perceived to be open-minded and with a sense of belongingness and camaraderie at all times that enable them to promote a harmonious relationship with the people around them. This finding supports the results of the study conducted by Curci et al. (2014) which showed that teachers' EI has a positive role in promoting students' achievement by enhancing the effects of students' self-perceptions of ability and self-esteem. Meanwhile, Rust (2014) also believed that emotional intelligence, as a construct, has the promise to provide meaningful answers about the successful working relationships between teachers and students in a classroom. He assumed that interpersonal relationship management, self-actualization and stress management capacities may someday prove to be one of the significant measures and indicators of teacher potential. 
Table 2.4

EI as perceived by themselves, principals'/school heads and pupils in terms of relationship management

\begin{tabular}{|c|c|c|c|c|c|c|c|c|}
\hline \multirow{2}{*}{ Self-management } & \multicolumn{2}{|c|}{ Students } & \multicolumn{2}{|c|}{ Teachers } & \multicolumn{2}{|c|}{ Principal } & \multicolumn{2}{|c|}{ Grand mean } \\
\hline & M & $\mathrm{D}$ & M & D & M & $\mathrm{D}$ & M & $\mathrm{D}$ \\
\hline $\begin{array}{l}\text { People usually feel inspired and encouraged } \\
\text { after talking with the teacher. }\end{array}$ & 3.56 & VEI & 3.56 & VEI & 3.38 & VEI & 3.50 & VEI \\
\hline $\begin{array}{l}\text { The teacher is approachable to the people who } \\
\text { need him/her. }\end{array}$ & 3.39 & VEI & 3.22 & EI & 3.62 & VEI & 3.41 & VEI \\
\hline $\begin{array}{l}\text { The teacher do understand and patient to those } \\
\text { people who have offended me. }\end{array}$ & 3.44 & VEI & 3.33 & VEI & 3.56 & VEI & 3.44 & VEI \\
\hline $\begin{array}{l}\text { People generally like the teacher even if they } \\
\text { don't always agree with him/her. }\end{array}$ & 3.41 & VEI & 3.22 & EI & 3.42 & VEI & 3.35 & VEI \\
\hline $\begin{array}{l}\text { The teacher mentors, give timely coaching, and } \\
\text { offer assignment that challenge and grow a } \\
\text { person's skill. }\end{array}$ & 3.60 & VEI & 3.11 & EI & 3.28 & VEI & 3.33 & VEI \\
\hline $\begin{array}{l}\text { The teacher acknowledges and reward pupil's } \\
\text { strengths, accomplishments, and development. }\end{array}$ & 3.67 & VEI & 3.56 & VEI & 3.51 & VEI & 3.58 & VEI \\
\hline $\begin{array}{l}\text { The teacher offers useful feedback and } \\
\text { identifies people's needs for development. }\end{array}$ & 3.64 & VEI & 3.56 & VEI & 3.56 & VEI & 3.58 & VEI \\
\hline $\begin{array}{l}\text { The teacher focuses his/her full attention when } \\
\text { he/she listens to another person. }\end{array}$ & 3.45 & VEI & 3.33 & VEI & 3.58 & VEI & 3.45 & VEI \\
\hline $\begin{array}{l}\text { The teacher is usually able to prioritize } \\
\text { important activities at work and get on with } \\
\text { them. }\end{array}$ & 3.69 & VEI & 3.33 & VEI & 3.49 & VEI & 3.50 & VEI \\
\hline The teacher listens well, seeks mutual & 3.78 & VEI & 3.33 & VEI & 3.51 & VEI & 3.54 & VEI \\
\hline Grand mean & 3.56 & VEI & 3.36 & VEI & 3.49 & VEI & 3.47 & VEI \\
\hline
\end{tabular}

\subsection{Academic performance of pupils}

Figure 1 displays the academic performance of pupils in the district under study. As reflected on the figure, out of the nine (9) schools in the district under study, pupils in School H got high ratings in their academic performance ranging from 90-94 described as "Very Good" while pupils in the majority of the schools achieved an academic performance with ratings ranging from 85-89 described as "Good".

This simply shows that the majority of the pupils in the district under study performed considerably good in their academic subjects. It implies that majority of the pupils are performing well academically. Lurea et al. (2011) has concluded that a good teaching method and style is reflected in the embodiment of training values and enhance their understanding and motivates students to think critically and believe in themselves. Rico and Sandoval (2020) supports this claim based on their findings which shows that implementation of emotional intelligence into classroom teaching effectively improve the academic achievement of primary school learners; however, they found a greater increase in academic achievement and higher teacher satisfaction in the game-based e-learning group. They concluded that emotional intelligence is the key towards academic competency. Parallel to these findings is the result of the study conducted by Lasarte et al. (2019) which disclosed that there exist a highest association between teacher support and academic performance, family support with emotional repair, and academic performance with emotional repair.

\subsection{On the influence of emotional intelligence to the academic performance of pupils}

Table 3 presents the Chi-Square test for independence on the influence of emotional intelligence to the academic performance of pupils. In terms of self-awareness, the test revealed an x2-value of 0.717 and $p$-value of 0.994 which is higher than alpha 0.05 level of significance thus, indicating insignificant result. This means that self-awareness do not significantly influence the academic performance of the pupils. It means further that whether the self-awareness of the teachers is very emotionally intelligent, it has nothing to do with the academic performance of pupils.

82 Consortia Academia Publishing (A partner of Network of Professional Researchers and Educators) 


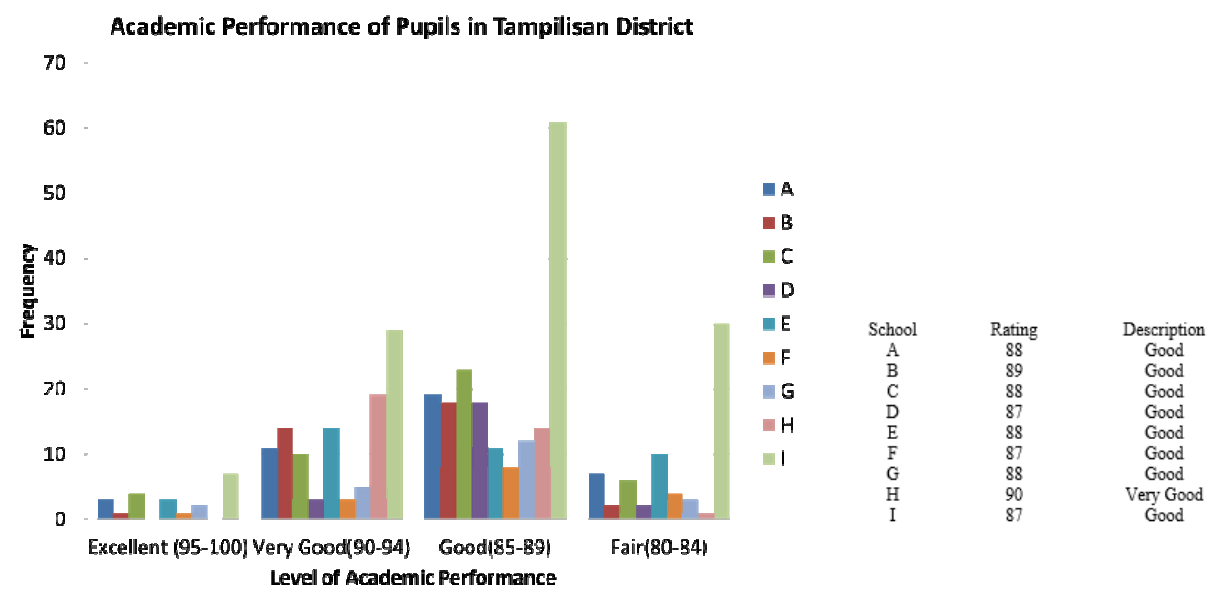

Figure 1. Academic performance of pupils in Tampilisan district

In terms of self-management, the test revealed an $\mathrm{x} 2$-value of 2.642 and $p$-value of 0.852 which is higher than alpha 0.05 level of significance thus indicating insignificant result. This shows that self-management do not significantly influence the academic performance of the pupils. It means that whether the self-management of the teachers is very emotionally intelligent, it has nothing to do with the academic performance of pupils. In terms of social awareness, the test revealed an $\mathrm{x} 2$-value of 4.405 and $p$-value of 0.622 which is higher than alpha 0.05 level of significance thus indicating insignificant result. This means that social awareness do not significantly influence the academic performance of the pupils, meaning, whether the social awareness of the teachers is very emotionally intelligent, it has nothing to do with the academic performance of the pupils. In terms of relationship management, the test revealed an x2-value of 6.125 and $p$-value of 0.409 which is higher than alpha 0.05 level of significance thus, indicating insignificant result. This means that relationship management do not significantly influence the academic performance of the pupils. It means further that whether the relationship management of the teachers is very emotionally intelligent, it has nothing to do with the academic performance of the pupils.

With these findings, Preeti (2013) declared based on the results of his study that academic achievement without emotional intelligence does not indicate future success and its absence indicates the weak personality and ability to build relations at the working place as well as in schools. The researcher believed that emotional intelligence is highly important for quality education. While the hypothesized finding of Rico and Sandoval (2020) on the emotional intelligence of teachers and the academic achievement of the learners claimed that there is no significant difference observed in the learner's achievement from the control group.

Table 3

Chi-Square test of influence of EI to the academic performance of pupils in Tampilisan district

\begin{tabular}{|c|c|c|c|c|c|c|c|c|c|}
\hline \multirow{2}{*}{\multicolumn{2}{|c|}{$\begin{array}{l}\text { Level of Emotional Intelligence } \\
\text { (EI) }\end{array}$}} & \multicolumn{4}{|c|}{ Academic Performance } & \multirow{3}{*}{$\begin{array}{c}\text { Total } \\
322\end{array}$} & \multirow{3}{*}{$\frac{\mathrm{x}^{2}-\text { Value }}{0.717}$} & \multirow{3}{*}{$\frac{p \text {-value }}{0.994}$} & \multirow{3}{*}{$\begin{array}{c}\text { Interpretation @ } \\
\alpha 0.05 \text { level of } \\
\text { significance } \\
\text { Not Significant }\end{array}$} \\
\hline & & \multirow{2}{*}{$\begin{array}{c}\begin{array}{c}\text { Excell } \\
\text { ent }\end{array} \\
18\end{array}$} & \multirow{2}{*}{$\begin{array}{c}\begin{array}{c}\text { Very } \\
\text { Good }\end{array} \\
91\end{array}$} & \multirow{2}{*}{$\frac{\text { Good }}{157}$} & \multirow{2}{*}{$\begin{array}{c}\text { Fair } \\
56\end{array}$} & & & & \\
\hline Self-awareness & Very EI & & & & & & & & \\
\hline & EI & 3 & 15 & 25 & 8 & 51 & & & \\
\hline & Less EI & 0 & 2 & 2 & 1 & 5 & & & \\
\hline Self-manageme & Very EI & 15 & 86 & 146 & 48 & 295 & 2.642 & 0.852 & Not Significant \\
\hline nt & EI & 6 & 21 & 37 & 17 & 81 & & & \\
\hline & Least EI & 0 & 1 & 1 & 0 & 2 & & & \\
\hline Social & Very EI & 13 & 82 & 145 & 52 & 292 & 4.405 & 0.622 & Not Significant \\
\hline awareness & EI & 8 & 25 & 37 & 12 & 82 & & & \\
\hline & Less EI & 0 & 1 & 2 & 1 & 4 & & & \\
\hline Relationship & Very EI & 15 & 83 & 150 & 48 & 296 & 6.125 & 0.409 & Not Significant \\
\hline management & EI & 5 & 24 & 32 & 17 & 78 & & & \\
\hline & Less EI & 1 & 1 & 2 & 0 & 4 & & & \\
\hline
\end{tabular}




\subsection{Difference on the level of emotional intelligence of the teachers}

Table 4 presents the Analysis of Variance on the difference in the level of emotional intelligence of the teachers as perceived by the three groups of respondents. It reflects that self-awareness and relationship management has the f-value of 7.016 and 3.785, respectively and has a $p$-value of 0.001 and 0.023 which is lesser than alpha 0.05 level of significance and revealed a "significant" result. Thus, the null hypothesis of no significant difference among the level of emotional intelligence as perceived by the three groups of respondents is rejected. This implies that the responses of the three groups of respondents are diverse in terms of self-awareness and relationship management levels. Further, using the Post-Hoc Analysis Multiple Comparison, result shows there exists a significant difference on the perception on the level of emotional intelligence in terms of self-awareness and relationship management between pupils and teachers' perceptions having pupils' perception that their teachers are very emotionally intelligent.

On the other hand, the $p$-value of 0.344 and f-value of 1.069 on self-management and 0.354 and f-value of 1.040 on social awareness which is greater than alpha 0.05 level of significance indicates "insignificant" result. Therefore, the null hypothesis is accepted. It implies that the respondents' perception towards these levels of emotional intelligence of teachers did not significantly differ among others. These results conformed to the study of Kauts and Saroj (2012) which stressed out that teachers with high emotional intelligence were having less occupational stress and more teachers effectiveness, whereas teachers with low emotional intelligence were having more occupational stress and less teacher effectiveness. Thus, emotional intelligence was found to be helpful in reducing occupational stress of teachers and enhancing their effectiveness in teaching. On the other hand, findings of Anwar and Fitriani (2020) also indicate that emotional intelligence, interpersonal communication, and adversity quotient positively correlate with each other, which leads to teachers' professional development and advantages to teachers' success.

\section{Table 4}

ANOVA on the difference among the level of EI of teachers as perceived by the three groups of respondents

\begin{tabular}{|c|c|c|c|c|c|c|c|}
\hline \multicolumn{3}{|c|}{ Variables } & \multicolumn{2}{|c|}{ Mean } & \multicolumn{3}{|c|}{ Description } \\
\hline \multicolumn{2}{|c|}{ Self-awareness } & Pupils & & & \multicolumn{3}{|c|}{ Very Emotionally Intelligence } \\
\hline & Teachers & & & & & \\
\hline \multirow{3}{*}{\multicolumn{2}{|c|}{ Self-management }} & Pupils & & & \multirow{2}{*}{\multicolumn{3}{|c|}{ Very Emotionally Intelligence }} \\
\hline & & Teachers & & & & & \\
\hline & & Principal & & & & & \\
\hline \multirow{2}{*}{\multicolumn{2}{|c|}{ Social Awareness }} & Principal & & & & & \\
\hline & & Pupils & & & \multicolumn{3}{|c|}{ Very Emotionally Intelligence } \\
\hline \multirow{2}{*}{\multicolumn{2}{|c|}{ Relationship Management }} & Teachers & & & & & \\
\hline & & Principal & & & & & \\
\hline \multicolumn{8}{|c|}{ ANOVA } \\
\hline \multicolumn{2}{|c|}{ Level of EI } & SS & Df & MS & $\mathrm{F}$ & Sig. & Int. \\
\hline \multirow[t]{3}{*}{ Self-Management } & Between Groups & .304 & 2 & .152 & 1.069 & .344 & Not Significant \\
\hline & Within Groups & 60.182 & 423 & .142 & & & \\
\hline & Total & 60.486 & 425 & & & & \\
\hline \multirow[t]{3}{*}{ Social Awareness } & Between Groups & .270 & 2 & .135 & 1.040 & .354 & Not Significant \\
\hline & Within Groups & 54.994 & 423 & .130 & & & \\
\hline & Total & 55.265 & 425 & & & & \\
\hline Relationship & Between Groups & 1.025 & 2 & .513 & 3.785 & .023 & Significant \\
\hline \multirow[t]{2}{*}{ Management } & Within Groups & 57.284 & 423 & .135 & & & \\
\hline & Total & 58.309 & 425 & & & & \\
\hline
\end{tabular}

\subsection{Proposed program to improve the teaching performance of teachers}

Table 5 displays the proposed program to improve the teaching performance of teachers. The proposed 
program includes the Emotional Intelligence live as well as self-paced online training programs and an innovative teaching/learning package to help improve the teaching and learning process which aimed to obtain a technology-wise innovation for teachers through training with the introduction of IVLE or Integrated Virtual Learning Environment. This is an e-learning management system that supports teachers and students' interaction over the web. It enables collaborative teaching and learning over the internet through a rich set of easy-to-use tools (Sun, 2001).

The Emotional Intelligence Online Training Program is also a complete course that dives deeper into strengthening the teachers' capacity of self-awareness, emotional management and emotional connection (IHHP, 2019). These activities can be done through training/seminar workshop involving teachers, School Principal/School Heads in coordination with the concerned agencies such as the Department of Education, Local Government Unit, Department of Social Welfare and Development and other concerned agencies or stakeholders to cater the needs of the teachers for its implementation. It can be done in 3-5 days.

This proposed program is in accordance to Dewi et al. (2016) who assert based on their findings that emotional intelligence has a positive and significant effect on teacher performance, it proves convenience in teaching and it allows teachers to conduct the learning process effectively. With these results, a recommendation for an empirically based Emotional Intelligence program was proposed by Maillefer and Saklofske (2018). They believed that this program is a direct and systematic component of professional development for teachers prior to and throughout their teaching careers.

\section{Table 5}

Proposed programs to improve the teaching performance of teachers

\begin{tabular}{llll}
\hline Proposed Programs & \multicolumn{1}{c}{ Objective } & \multicolumn{1}{c}{$\begin{array}{c}\text { Activities/ } \\
\text { Strategies }\end{array}$} & $\begin{array}{l}\text { Timplementing Body } \\
\text { Frame }\end{array}$ \\
\hline $\begin{array}{l}\text { A. Emotional } \\
\text { Intelligence Online }\end{array}$ & $\begin{array}{l}\text { Strengthen teachers' capacity } \\
\text { of self-awareness, emotional } \\
\text { management and emotional } \\
\text { connection }\end{array}$ & $\begin{array}{l}\text { Interactive and } \\
\text { collaborative live as } \\
\text { well as self-paced } \\
\text { online training }\end{array}$ & $\begin{array}{l}\text { DepEd, LGU, DSWD } \\
\text { and other concerned } \\
\text { agencies or } \\
\text { stakeholders }\end{array}$ \\
$\begin{array}{l}\text { B. Innovative } \\
\text { Teaching/ Learning } \\
\text { Package through } \\
\text { IVLE }\end{array}$ & $\begin{array}{l}\text { Obtain technology-wise } \\
\text { innovation in teacher } \\
\text { training with the introduction } \\
\text { of IVLE. }\end{array}$ & $\begin{array}{l}\text { Conduct of seminar } \\
\text { about teaching/learning } \\
\text { package }\end{array}$ & 3-5 days \\
& $\begin{array}{l}\text { Obtain knowledge/ } \\
\text { skills to interact with their } \\
\text { pupils through the web such } \\
\text { as zoom, google meet, } \\
\text { messenger, Facebook, and } \\
\text { etc. }\end{array}$ & $\begin{array}{l}\text { Conduct of } \\
\text { training/seminar } \\
\text { workshop to teachers }\end{array}$ & $\begin{array}{l}\text { on the use of } \\
\text { technology over the } \\
\text { web }\end{array}$ \\
\hline
\end{tabular}

\section{Conclusion}

The prevalent emotional intelligence of teachers in the district under study is self-awareness. They are perceived to be very emotionally intelligent. Their pupils' academic performance is considerably good. The emotional intelligence of teachers did not significantly influence the pupils' academic performance. A significant difference existed on the emotional intelligence level of teachers in terms of self-awareness and relationship management while insignificant on self-management and social awareness.

\subsection{Recommendations}

In light of the findings and conclusions of the study, the following are hereby recommended:

$>$ Schools must develop and promote seminars/training that aid the teachers in exercising control over their emotions, especially those that deal with self-management, social awareness and relationship 
management.

$>$ Teachers' should implement differentiated activities in class to motivate pupils to gain interest in improving their academic performance into a very good, if not excellent.

$>\quad$ Another study can be conducted in other districts to determine if similar conditions exist.

\section{References}

Akmal, M., Mohzan, M., Hassan, N., \& Halil, N. (2013). The influence of emotional intelligence on academic achievement. Procedia - Social and Behavioral Sciences, 90, 303-312. https://doi.org/10.1016/j.sbspro.2013.07.095

Alam, A., \& Ahmad, M. (2018). The role of teachers' emotional intelligence in enhancing student achievement. Journal of Asia Business Studies, 12(1). https://doi.org/10.1108/JABS-08-2015-0134

Andinalgnat, A., \& Clipa, O. (2012). Teachers' satisfaction with life, job satisfaction and their emotional intelligence. Procedia - Social and Behavioral Sciences, 33, 498-502. https://doi.org/10.1016/j.sbspro.2012.01.171

Anwar, M., \& Fitriani, S. (2020). Emotional intelligence and interpersonal communication: Their relationship on primary school teachers' adversity quotient. International Proceedings Conferences Series, 55-67.

Asrar-ul-Haq, M., Anwar, S., \& Hassan, M. (2017). Impact of emotional intelligence on teacher's performance in higher education institutions of Pakistan. Future Business Journal, 3(2), 87-97. https://doi.org/10.1016/j.fbj.2017.05.003

Baracsi, A. (2016). Emotional intelligence of Hungarian teachers. Universal Journal of Educational Research, 4(7), 1734-1743. https://doi.org/10.13189/ujer.2016.040728

Curci, A., Lanciano, T., \& Soleti, E. (2014). Emotions in the classroom: The role of teachers' emotional intelligence ability in predicting students' achievement. The American Journal of Psychology, 127(4), 431-445. https://doi.org/10.5406/amerjpsyc.127.4.0431

Dewi, E., Bundu, P., \& Tahmir, S. (2016). The effect of emotional intelligence, competence and interpersonal communication on the performance of senior high school teachers through achievement motivation in Makassar, Indonesia. The New Educational Review Journal, 44(2), 176. https://doi.org/10.15804/tner.2016.44.2.14

Dolev, N., \& Leshem, S. (2016). Developing emotional intelligence competence among teachers. International Journal of Teachers' Professional Development, 21(1), 21-39. https://doi.org/10.1080/13664530.2016.1207093

HelpGuideOrg International. (2020). Improving emotional intelligence or EQ. Retrieved January 15, 2020, from https://www.helpguide.org/articles/mental-health/emotional-intelligence-eq.htm

Lasarte, O., Diaz, E., \& Saez, I. (2019). Academic performance, perceived social support and emotional intelligence at the university. European Journal of Investigation in Health, Psychology and Education, 9(1), 39-49. https://doi.org/10.30552/ejihpe.v9i1.315

Lopez, S., Bakker, A., \& Extremera, N. (2019). How does emotional intelligence help teachers to stay engaged? Cross-validation of a moderated mediation model. Elsevier - Personality and Individual Differences, 151, 109-393. https://doi.org/10.1016/j.paid.2019.04.048

Lurea, C., Neacsu, I., Safta, C. G., \& Suditu, M. (2011). The study of the relation between the teaching methods and the learning styles - The impact upon the students' academic conduct. Procedia Social and Behavioral Sciences, 11, 256-260. https://doi.org/10.1016/j.sbspro.2011.01.072

Maillefer, A., \& Saklofske, D. (2018). Emotional intelligence and the next generation of teachers. Emotional Intelligence in Education (pp. 377-402). https://doi.org/10.1007/978-3-319-90633-1_14

Mayer, J., \& Salovey, P. (1997). Daniel Goleman's emotional intelligence. Philosophy 101(1) Goleman: Retrieved January 4, 2020, from https://web.sonoma.edu/users/s/swijtink/teaching/philosophy_101/paper1/goleman.htm\#: :text=\%22E motional\%20intelligence $\% 20$ is $\% 20$ the $\% 20$ ability,promote $\% 20$ emotional $\% 20$ and $\% 20$ intellectual $\% 20 \mathrm{gr}$

86 Consortia Academia Publishing (A partner of Network of Professional Researchers and Educators) 
owth. $\% 22$

O'Shea. (2019). The role of teacher emotional intelligence in determining relationship quality with students' miles. ProQuest Dissertations Publishing, 1-24. Retrieved January 15, 2020, from https://knowledge.library.iup.edu/cgi/viewcontent.cgi?article $=2622 \&$ context $=$ etd

Preeti, B. (2013). Role of emotional intelligence for academic achievement for students. Research Journal of Education Sciences, 1(2), 8-12.

Rico, T., \& Sandoval, I. (2020). Can academic achievement in primary school students be improved through teacher training on emotional intelligence as a key academic competency? Frontiers in Psychology, 10, 2976. https://doi.org/10.3389/fpsyg.2019.02976

Roja, M., Panimalar, N., and Sasikumar, L. (2013). A study on emotional maturity and self-concept at higher secondary level. Research in Psychology and Behavioral Sciences, 1(5), 81-83. https://doi.org/10.12691/rpbs-1-5-4

Rust, D. A. (2014). Relationship between the emotional intelligence of teachers and students' academic achievement. Theses and dissertations - Educational Leadership Studies, 8, 1-126.

Sun, J. (2001). Integrated virtual learning environment (IVLE) 3.0. The HKU learning hub (pp. 1-27). Retrieved March 5, 2020, from https://core.ac.uk/download/pdf/37883047.pdf

The Institute for Health and Human Potential. (2019). Unleash emotional intelligence to work better, together. training programs. Retrieved March 5, 2020, from https://www.ihhp.com/emotional-intelligence-training/

Tolloczko, A. (2015). Educational competences and emotional intelligence level of teachers. Pedagogics, psychology, medical-biological problems of physical training and sports, 2, 60-63. https://doi.org/10.15561/18189172.2015.0210

Valente, S., Monteiro, A. P., \& Lourenco, A. A. (2019). The relationship between teachers' emotional intelligence and classroom discipline management. Psychology in the Schools, 56(5), 741-750. https://doi.org/10.1002/pits.22218

Vesely, A., Saklofske, D., \& Leschied, A. (2013). Teachers - the vital resource: The contribution of emotional intelligence to teacher efficacy and well-being. Canadian Journal of School Psychology, 28(1), 71-89. https://doi.org/10.1177/0829573512468855 
Mansanadez, E. A.

88 Consortia Academia Publishing (A partner of Network of Professional Researchers and Educators) 